\title{
Brownfield redevelopment by the private sector: market driven decision making
}

\author{
I. L. Whitman
}

The Whitman Companies, Inc., East Brunswick, N.J., USA

\begin{abstract}
Most successful Brownfield redevelopment in North America involves a partnership of interests between government and private developers. Much has been written of the need for "Public-Private Partnerships", as well as community involvement as contaminated Brownfield sites are recycled into economic productivity. Less well understood are the motivation and incentives for private investors and developers to take the risks necessary to succeed at Brownfield redevelopment, and the criteria used by the development community to determine when to do so.

The National Association of Industrial and Office Properties (NAIOP), of Herndon, Virginia, represent the largest and most experienced owners and developers of commercial real estate in North America. NAIOP is one of the few private sector organizations that has worked with USEPA and other public agencies to promote and enhance the understanding of the private sector opportunities and risks in Brownfield redevelopment. Interviews were conducted with NAIOP members and other Brownfield players regarding the market drivers that motivate private developers and their financial backers to invest their time and resources in Brownfield restoration and redevelopment, and the issues which stand in the way of such investment. Information developed from interviews and discussions with developers, and from NAIOP presentations at EPA's National Brownfields Conferences and from commercial real estate forums are cited and factored into the analysis of private sector forces that lead to success in Brownfield redevelopment.
\end{abstract}




\section{Introduction}

In North America over the past decade, scholars and practitioners alike have worked to establish and promote a growing concept and practice geared to the revitalization and redevelopment of a myriad of Brownfield sites. Brownfields were first recognized for their environmental challenges, and subsequently for the many public policy and legal issues that were identified, and in time, largely solved. It is safe to say that as the technical, legal and regulatory elements of Brownfield redevelopment have been made manageable, the challenge going forward rests primarily with the private sector who provides the capital, skill and entrepreneurial energy necessary to actually transform substandard real estate into renewed resources with both private, and public benefits.

The workings of Brownfields redevelopment did not come smoothly or naturally to the real estate industry which cherishes predictability and freedom from risk. However, the prospect of new access to old land, and the difficulty of access to undeveloped land has led the real estate development and investment sector reluctantly but steadily into the Brownfield marketplace.

Real estate professionals associated with Brownfield activities agree that first and foremost, their decisions are governed by the real estate marketplace in which they operate.

\subsection{National perspective}

Thomas Bisaquino, president of the National Association of Industrial and Office Properties (NAIOP), a business association of major commercial developers in North America cites the lack of developable land in many of the older, more densely populated regions of the U.S. and Canada as providing the pressure to NAIOP's members to consider Brownfield sites in and near urban areas. Bisaqaquino indicated that approximately 20 of the 50 major U.S. real estate markets have evolved to where Brownfield redevelopment can compete with other development for investor capital and developer energy. These markets include most of the northeast corridor from Boston to Baltimore, Pittsburgh, Cleveland and Chicago.

Some of the demand for urban redevelopment is fueled by lifestyle demands among the aging "baby boomers" who are rediscovering urban centers and moving back to center cities from suburban locations where they grew their families. The market pressure is for so-called "lifestyle centers" where the population can live, work and play without continuing their dependence on automobile use. Infill development, selecting substandard parcels and groupings of properties in otherwise viable urban centers provides an attractive resource for developers to enhance sub value land, satisfy the lifestyle center demand, and make a reasonable profit. In every urban area, some of these infill properties will be environmentally suspect and warrant the full measure of Brownfield site due diligence, investigation and remediation. 


\subsection{Factors influencing market-based decisions}

A wide variety of factors intersect with the real estate marketplace and the players in that marketplace that shape the individual decisions made by developers and investors over Brownfields. Factors that have been cited include risk and liability, return on investment, value creation, investor goals, developer profile, market changes, and government interaction.

\section{Liability and risk}

It can be said that successful Brownfield redevelopers hate liability and love risk.

\subsection{Liability}

Environmental liability was once the single most important factor in stifling Brownfield redevelopment. Under U.S. federal law, and state law as well, the liability for environmental contamination to properties is "joint and several", meaning each property owner in the chain of title back to when the contamination occurred is liable potentially for the entire cost of cleanup and environmental restoration. Under these conditions, investors and developers would not dare to consider acquiring property unless the full extent of environmental damage was known, and the property was well on its way toward complete remediation, a circumstance seldom applicable to under-utilized, devalued real estate. Attorneys would strongly advise clients not to venture into such shark-infested waters as a potential Brownfield site, and bankers would see to it that funds were not loaned for such purposes, lest they be somehow brought into the chain of liability themselves.

Susan Boyle, of the New Jersey Department of Environmental Protection (now on leave to the National Brownfield Association) assisted developers attracted to Brownfields by negotiating Prospective Purchasers Agreements on behalf of the state, and by providing developers with counseling on liability protection and reduction under the state's Brownfield statutes and regulations. Ms. Boyle has indicated that as developers become more sophisticated in such matters, the more confident they are in venturing into the Brownfields marketplace.

\subsection{Risk}

Dwight Stenseth, Managing Partner of Cherokee Investment Partners, Denver, Colorado, sees all prospective redevelopment properties as "risk adjusted", including environmental risks. Cherokee is exclusively a Brownfield redeveloper, using funds accumulated from investors who understand that all real estate carries some risk, and Brownfield sites may, on the average, carry a higher rate of risk. Stenseth indicates that to attract major investors, the return must be equal or greater than other real estate investment opportunities. Cherokee's investor base includes such establishment stalwarts as government pension funds, corporate pension funds and university endowments. 
Several players in the real estate marketplace see Brownfields development as being about managing risk. Kenneth Cohen, owner/operator of Pantheon Properties of New York City, indicates that each investor and developer has a risk profile, which is related to anticipated return on investment. He believes that smaller, more entrepreneurial developers such as Pantheon must manage risk by having better knowledge of the real estate market, and substantial experience to know when environmental risk may become unmanageable. While insurance products are very valuable in helping a Brownfield developer manage risk, the insurance underwriters themselves succeed only through their knowledge and experience in dealing with the factors that create environmental risk.

Cohen and William Klein of Kay Realty Holdings, Ocean, New Jersey point out that all real estate investment and development entail risk, including the ultimate performance of the property in retaining tenants and producing an income stream necessary to provide the targeted return on investment.

\section{Value and return}

As entrepreneurial driven business people, developers and investors are motivated by the "bottom line", i.e., at the end of the day will the return on their efforts and investments provide the financial yield that could be obtained through alternative investments?

\subsection{Value}

Several of the developers interviewed, including Michael Perlman of Holualoa, Arizona of Tucson, Arizona, emphasize that Brownfield redevelopers "create value" by converting under-utilized properties to commercial assets that attract and retain tenants. Perlman, whose company acquires, restores and operates rundown, sub-value retail centers, does not look for Brownfield sites per se, but seeks to acquire property past its prime, physically inferior to newer developments, in areas where the upgrading of the facility will be accompanied by the demand for occupancy and the return of customers. Such facilities are often found in older suburban regions, where retail strip malls and shopping centers may be 35 to 55 years old, and environmental issues may include asbestos insulation, discharges from dry cleaning establishments and aging or no longer operating gasoline stations.

Cohen, of Pantheon Properties, is motivated by "fixing things and creating value". In the New York metropolitan area, Cohen finds that there are aging property owners holding sub-value properties, offering their properties at discount rates so that they can escape from the responsibilities of environmental liability and remediation. In some cases, these owners no longer have current knowledge of the commercial real estate market, a void which Cohen can fill and find the opportunity to restore the property to both its physical condition and its commercial value. 


\subsection{Return on investment}

Return on investment is the standard by which most investments are assessed. In the development business, investors are the partners of developers. Whereas banks and other lenders may be involved at some stages in the process, particularly with smaller developers, capital is most often obtained through investor-partners. Investors set their sights on different levels of return depending on their obligations to the individuals or the institutions from whom the funds are raised. Stenseth indicates that Cherokee creates large scale investment funds, they raise money and are capital providers. Once created, the funds are invested in new redevelopment projects where the return on investment must exceed the obligations established to provide the investors with a competitive yield. Investors may be taken out of the project through a variety of complex financial structures that may range from high yield bonds, to secure loan repayments, to long term equity positions in the real estate market.

\section{Owner-driven development}

It is often believed that Brownfield redevelopment is driven largely by government authority seeking to restore and upgrade blighted areas, and by commercial developers motivated by a series of market forces. There are instances, however, where long-standing property owners are driving the process.

Donald Eisen, of Cushman and Wakefield of northern New Jersey, is a highly experienced broker in the commercial real estate market in the New York metropolitan area. Eisen has recently redefined his practice to focus on major corporate clients who have "mothballed" industrial properties no longer essential to their industrial operators. Eisen's experience is that this class of property owner, quite substantial in certain locations, are looking not to redevelop their properties but to tap into the benefits of the real estate marketplace to bring about favorable sales of their property to potential redevelopers. In general, corporate owners are not expert in matters of real estate value, and Eisen and other senior brokers bring their expertise into this process on behalf of their clients.

Eisen indicates that his corporate clients are not motivated solely by the potential sale price of their property. He believes that corporate land owners desire to have the properties restored in a manner to create compatible uses with the community, so that their "brand name" property, which may have been a community icon for as long as a century or more, can be retired with a positive image that brings about a favorable reception from community leaders as the property is transformed from its present inactive use to its future identity.

\section{Developer profile}

Research shows that there are a wide variety of Brownfield redevelopers, and that the profile of the developers will largely determine the type of investment, 
the tolerance for risk, and the manner in which market forces drive their redevelopment objectives.

\subsection{Size}

In general, Brownfield redevelopers are smaller than the major commercial, industrial and residential developers whose prime motivation is to generate "product" in order to maintain a high volume of business and the continuous flow of revenue. However, in the regions of the U.S. cited by Bisaquino as "prime" Brownfield territory, major developers who never intended to get into Brownfields are now actively seeking out distressed properties because in some cases there are few other options. Throughout the northeast, major homebuilders are now developing substantial townhouse and condominium residences at Brownfield locations, because of the demand for and high value placed upon such locations. In some cases, the value of such "lifestyle" residences exceeds the value of comparable suburban prospects by several fold.

Perlman and Cohen point out that smaller developers need to be more entrepreneurial and selective in determining the projects that work for them. These "niche" players generally attract investors seeking higher returns who are more tolerant of the risks that may accompany real estate markets that center around Brownfield situations. Cohen indicates that the "big players" drive land prices up and return down, a financial reality that may satisfy their more conservative investors, but not the needs of the "niche players".

\subsection{Niches}

Smaller developers seek out and exploit niche situation because that is where their creativity, knowledge and experience can enable them to out-compete the larger companies whose financial expectations require them to look more broadly and globally at real estate markets. Bradley Tate, of Westrum Development Company located near Philadelphia, Pennsylvania, indicates that his company evolved into Brownfield development because, in their market area, that is where they found the most viable opportunities. Westrum, a niche player, "seeks redevelopment/revitalization opportunities in inner city and aging suburban towns and boroughs". In the greater Philadelphia area, they found that these opportunities came at "former industrial and manufacturing facilities with significant environmental challenges". Among the forces that will drive a successful deal for Westrum are "strong market conditions" and "high profit potential".

\subsection{Knowledge and experience}

Successful Brownfield developers believe that their particular experience and knowledge give them an important advantage in their marketplace. In some cases, knowledge of environmental issues is cited as an advantage, but, in truth, this specialized knowledge can be obtained externally by working with experienced environmental consultants who understand the complexities of 
remediation in the Brownfield marketplace. More importantly, it is real estate expertise that is invaluable. Knowledge of tenants, government approvals and land use restrictions, and the financial marketplace are most essential.

It is no accident that the interviews conducted in the preparation of this paper were with successful players in the Brownfields marketplace, whose expertise has sustained them throughout their business enterprises. Obviously, the unsuccessful players, who are no longer participating in Brownfields redevelopment, are neither available nor in some cases aware that lack of marketplace expertise may have contributed to their failures.

\section{Conclusions}

Although conceived as a means of remediating contaminated property and reducing hazards to the environment, Brownfield redevelopment, in the final analysis, is a real estate concept that will succeed or fail, in each case, based on real estate principles. The majority of Brownfield sites restored, and value created will be done so at the hands of the private sector.

It is clear that entrepreneurial redevelopers hold the keys to the Brownfield domain, and that they are largely driven by conventional real estate market forces, forces that are likely to rise and fall with the tide of the real estate marketplace. 